\title{
HOLIDAYS AND WEEKDAYS OF HUNGARIAN TOY TRADITIONS \\ (RECALLING RECENT PAST WITH FUTURE PICTURES)
}

\author{
József KRISTON VízI \\ SZÓRAKATÉNUSZ Toy Museum and Workshop \\ H-6000 Kecskemét, Gáspár A. u. 11, Hungary
}

'Playing is a drug that isn't followed by hangover.' Endre GRASTYÁN (1924-1988)

The thoughts, questions and maybe not too original statements below have forced me to write my thesis for quite a long time. Namely, to take an exciting walk on the territory of the culture of toys and playing, - knowing or at least guessing that behind every step there have been petty battles or great struggles for playing itself for the last two decades.

The pampered decision was forced to become true by the fact that the events in connection with playculture in the period of 1975-1983 can be examined from a certain distance with the help of many different publications, showing different intentions and ambitions. Their authors are happy to express their opinion. It is important because taking everything into consideration it seems to me that artists, popular educators, museologists, engineers, foresters and writers have had the same thing on their mind. They have been finger and thumb for a long time. Their reasons for acting so could be best revealed in an anthology or rather in a breviary.

But till then in the first part of my present thesis I would like to speak about the period before 1981 when the Hungarian Toy Museum and creative toy-preparing and craft workshop named SZÓRAKATÉNUSZ was established in Kecskemét. In the second part I am going to speak about manifestations of professional and social agents in connection with playing. In the third part I am going to draw conclusions and set up aims that come from the things mentioned above and move us towards new, quality degrees. Those dealing with toys as professionals in Hungary and in Europe and some civil societies have found their ways towards each other but their influence is often at the mercy of social movements, thus their activity is changeable and often restricted.

As this unsteadiness influences our possibilities the answer strategies may seem a bit deviant and extreme. In our case it brings the possible and necessary alternative of 'forward escaping' into being. The Hungarian toy and play centre planned in 1978, opened in 1981 grew over its walls and spiritual barriers.

We are going to give a summary of preparations for the holidays, periods and weekdays between them. 


\section{A) THE BEGINNINGS}

The folklore-discovering and object-creating tendencies became stronger in the middle of the 1970s. The members of The Folkart Studio for Young People were recruited from mostly town youngsters, who worked in folklore camps in FaddDombori and in Tokaj. ${ }^{1}$ The renewed play-producing that is important from our point of view first appeared in collective form in 1975 in Tokaj Creative Camp organised by the Popular Education Institute and sponsored by the National Educational Council. ${ }^{2}$

The spectacles of the Budapest International Fair influenced the INTERPLAYEXPO, where the amateur toy creators did not have too many chances to introduce their playthings, but later the children's playground at the Országos Mezógazdasági és Élelmiszeripari Kiállítás (OMÉK) and certain tenders gave an opportunity to introduce these creative toys. ${ }^{3}$ These years plaything creating activities became more and more accepted (in Budapest, Pécs, Salgótarján, Zalaegerszeg, Orosháza, Csillebérc or Kecskemét), the names of their creators (Mária Kardos, Mari Nagy, István Vidák, János Dugár, Kristóf Nagy) sounded more familiar. ${ }^{4}$

The most important moment in connection with our present topic was the beginning of the 'playhouse project' by the Popular Education Institute in 1978. The experiment started in four culture centres in four different parts of the country (Szombathely, Budapest-Újpalota, Kecskemét, Jászkisér) and lasted until the end of 1981. ${ }^{5}$ It was also an important event at the end of 1978 that the UNESCO held its experts' meeting in Budapest under the title 'The influence of the technical civilization on the traditional culture and folkart', and the idea of a conference to be held in Hungary was brought up here (Kecskemét-Budapest, 1982). ${ }^{6}$

The ELTE's [Eötvös Loránd Tudományegyetem Budapest (Eötvös Loránd University)] 'folklorism' research project led by Vilmos VoIGT was one of the methodological and theoretical research centres, and had more and more characteristic programmes ${ }^{7}$ from the end of 1978. The author of the present paper - finishing his university studies - led a toy and data collector team in some villages of the Bükk mountains in the summer of 1978 with the help of a self-compiled questionnaire. So

\footnotetext{
1 BÁTHORY (1981: 102); ZELNIK (1981: 6-9).

2 BÁNSZKY (1976: 6-8). To the history of amateur movements and activity of Tokaj FNS see MAKOVECZ (1981: 91-101).

3 PIRK (1979: 262-264).

${ }^{4}$ PIRK (1979: 239-269).

5 HOLLós (1982: 32-33). She mentions that 20 culture centres and pioneer houses joined the four experimental playing houses in 1980-1981.

6 ZELNIK (1982b: 34).

7 VOIGT (1979). The department started a toy and play collecting programme with the help of Imre KATONA, Emese KOVÁCS and others. See: KATONA (1981), KOVÁCS (1983) and POLÁK (1981).
} 


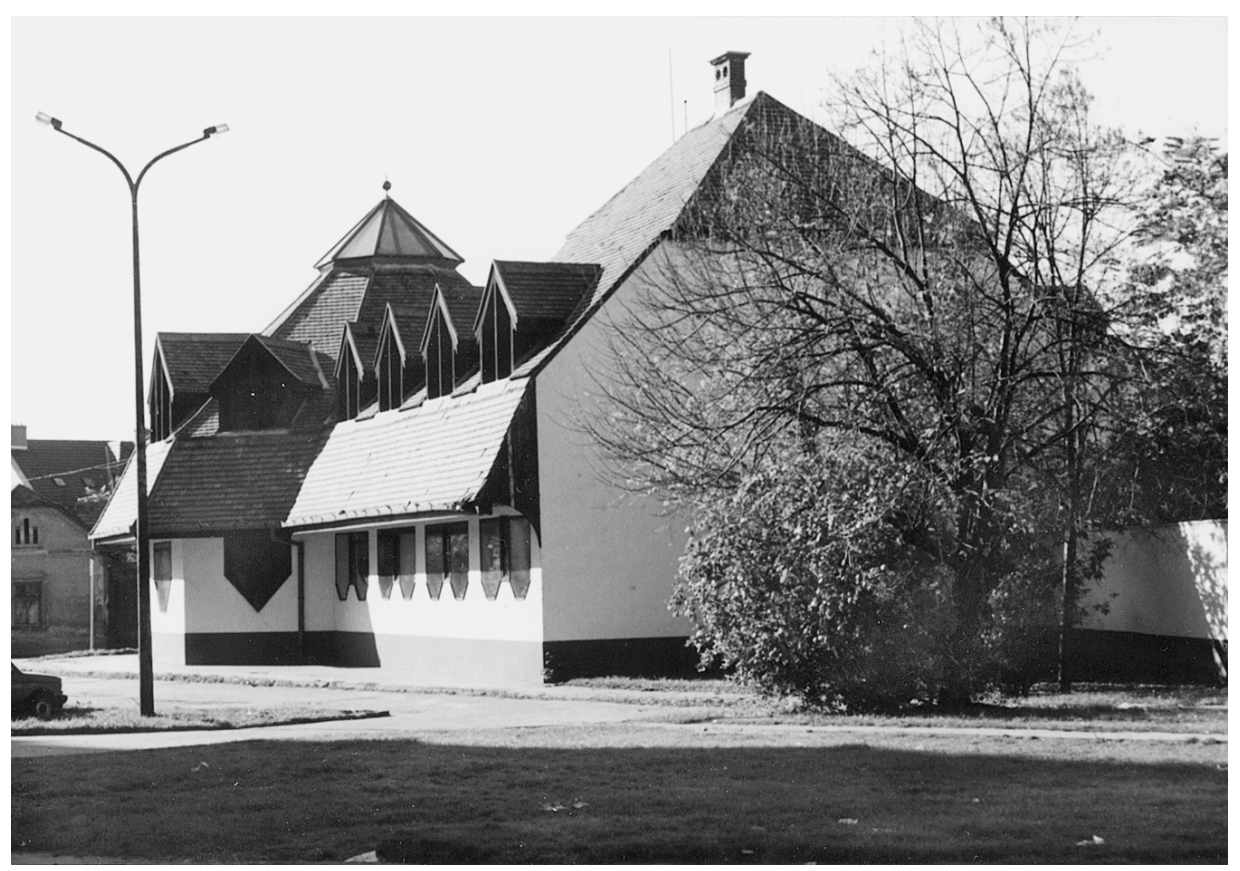

Fig. 1. The building of "SZÓRAKATÉNUSZ" Toy Museum and Workshop

these camps were supported by toy collectors. ${ }^{8}$ The year of 1979 was declared International Children's Year by the UNESCO, and this drew the attention to worldwide problems of children's life. In our country it was filled with a lot of charity activities. The artists and the intellectuals made the most of the 'existing socialism' that considered itself to be sensitive to children's problems. Ethnography and museology turned to its earlier well studied object: the socio-ethnographical aspects of children's life. As a result of this a lot of exhibitions were organized in Veszprém ${ }^{9}$, Vác ${ }^{10}$, Miskolc $^{11}$ and in the Museum of Ethnography, Budapest ${ }^{12}$. In October 1979 a conference was held related to the exhibition 'Children's life in the old Hungarian village' organized by Erzsébet GYÖRGYI. The lectures were published in Ethnographia in $1981^{13}$.

${ }^{8}$ KRISTON Vízi (1978). The toy-collecting started in the National Educational Student camp, and the toy pieces were given to the county museums of Nagykanizsa, Eger, Nyíregyháza, Győr, Mosonmagyaróvár and Miskolc.

${ }^{9}$ S. LACZKOVITS (1980: 237-272).

10 Organised by V. IGAZ, Mária in the museum of Vác (Vak Bottyán Museum).

${ }^{11}$ Exhibition "Azok a gyerekek..." (Those were the children...) organised by Ernő KuNT (died in 1994 ) in the museums of Mezőkövesd and Miskolc (North-Eastern Hungary).

12 GYÖRGYI (1983: 13-25). The booklet appeared in 1982 on the occasion of the UNESCO Conference in Kecskemét.

13 E.g. K. CSILLÉRY (1981: 61-65); GUNDA (1981: 65-68). 


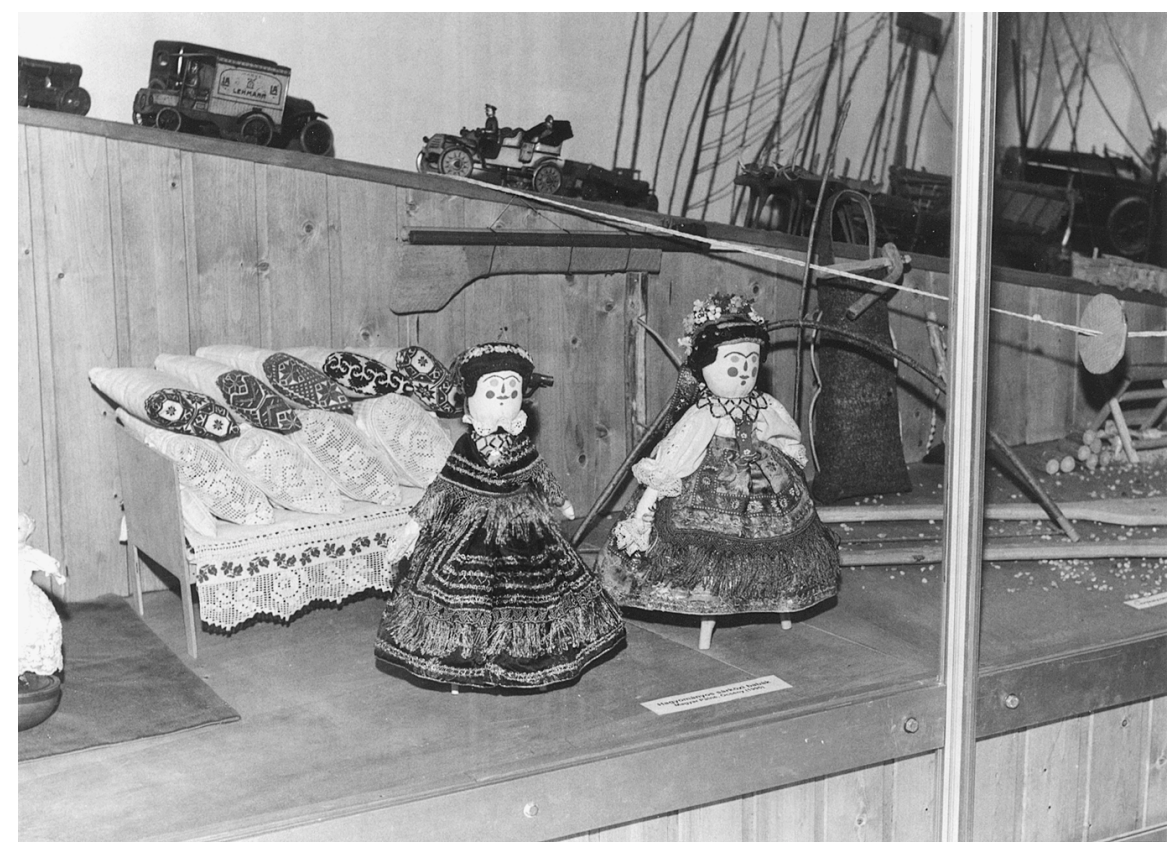

Fig. 2. Detail of the permanent exhibition

In the same year another exhibition entitled 'Play culture' was opened in the Hungarian National Gallery. The exhibition guide was written by József ZELNIK ${ }^{14}$, and Mrs Róbert Hollós gave a summary of the experimental work of the Gallery ${ }^{15}$.

The publishing companies could not keep pace with the increasing interest aroused by the children's year, but public attention was driven by monographies on toys made of plants ${ }^{16}$ or play activities in Hévizgyörk ${ }^{17}$ that appeared in 1980. In the same year an important book 'Children's world in Esztelnek'18 by Klára GAZDA was published. It dealt with children's life, toys and playing activities. These years gave a push to studying the changing social life and entertainment of Hungarian young people $^{19}$. The best publications between 1979 and 1982 were a summary on hop$\operatorname{scotch}^{20}$, a monography on nursery rhymes ${ }^{21}$, two volumes on the children's folklore in Slovakia today by József GÁGYOR ${ }^{22}$ and a play-literature anthology by József

14 ZELNIK (1982a: 109-113).

15 HOLLÓs (1982b: 105-107).

16 NAGY-VIDÁK (1980).

17 HiNTALAN-LÁZÁr (1980).

18 After this Klára GAZDA published an important paper on the parallelism of Hungarian and Rumanian play activities. (Data from Kovászna county between 1974-1978). GAZDA (1981: 247-268).

19 KOMLÓSI (1979: 92-105); KRISTON VÍZI (1981: 309-321)

20 KARLÓCAI (1981).

${ }^{21}$ FARAGÓ-FÁBIÁN (1982).

${ }^{22}$ Prepared earlier but published only in 1982. 


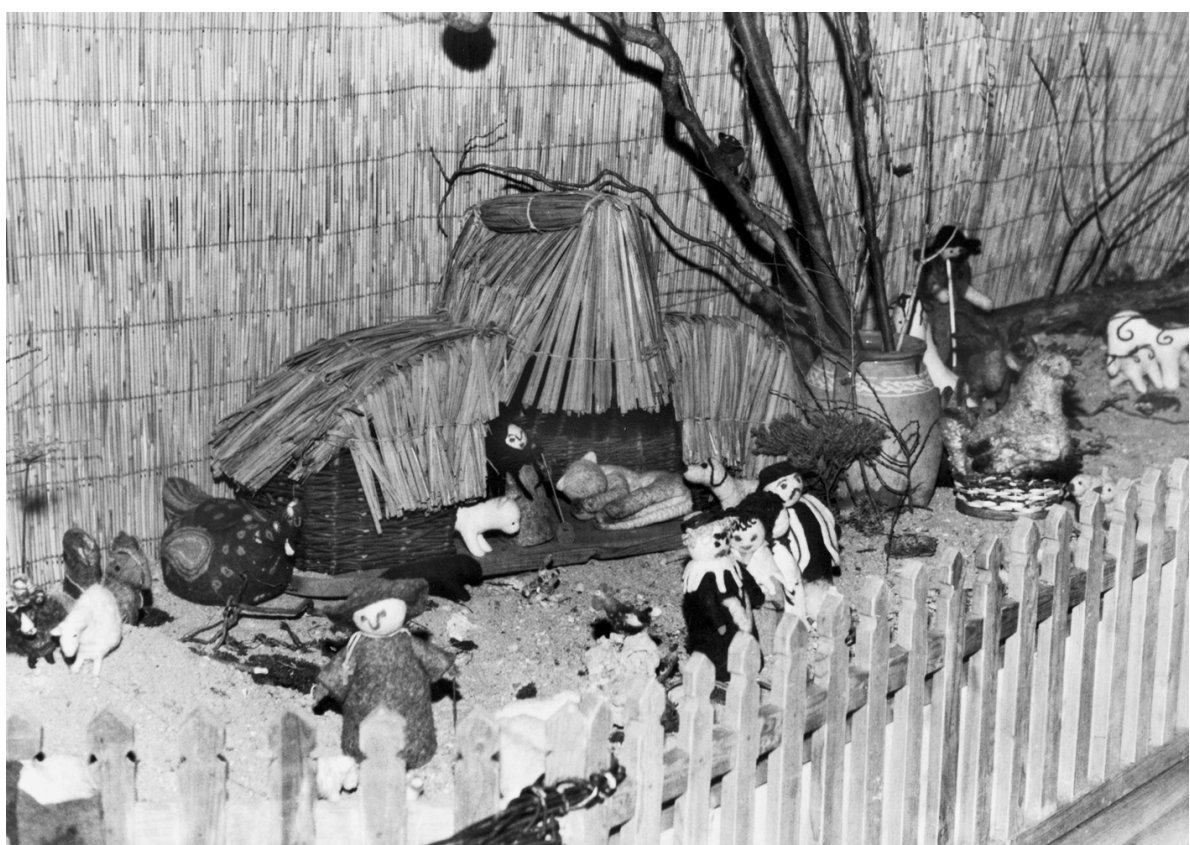

Fig. 3. "Toys made of felt, from all the world" - exhibition in 1996

ZELNIK ${ }^{23}$. The above mentioned ELTE project made it possibile to organize an international meeting of folklorists in Kecskemét again in 1981. Two important books were published on this occasion: a collection about the ten years of the so-called 'nomad generation' and four volumes on concepts and phenomena of folklorism compiled by Kincsố VEREBÉLYI ${ }^{24}$.

\section{B) FROM THE PLAYHOUSE TO THE SZÓRAKATÉNUSZ (1978-1981)}

Popular educationists say that the visual creative-educational programme series organized by the Erdei Ferenc Culture Centre (opened in Kecskemét 1975) was memorable and really useful - especially for primary school pupils. Singing, music, dance, creative dramas with the help of amateur folklorists and professional artists were organized, later playhouse days and weekends took part in forming children's life between 1978 and 1981. These were often mentioned as experiments ${ }^{25}$. And we can already find important personalities here such as Ágnes Szögi, János Bereg-

\footnotetext{
23 ZELNIK (1982b).

${ }^{24}$ Between 27-29th July, 1978, a conference was organised under the title Folklorism at one time and today.

25 ZELENÁK (1981: 28-30).
} 


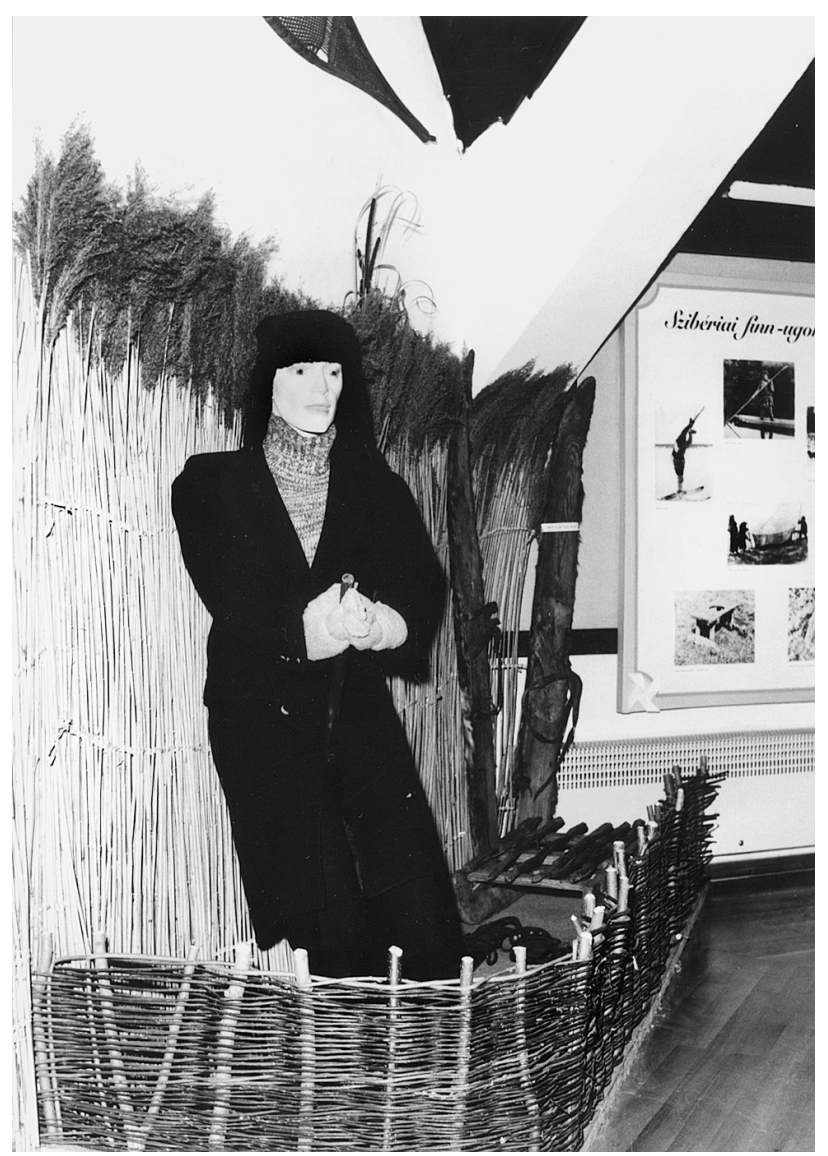

Fig. 4. "Traditional sports and folk games at finno-ugric nations" - exhibition in 1997

szászi, Kristóf Nagy, Mrs Margit Kalmár Horóczi, Lajos Kálmán, Rozál Rácz, János Dugár who made a contribution to the arts and folkarts of this region.

So the forces bringing our institute into being are a part of the intellectual continuity. Pál BÁNSZKY's suggestion should be mentioned here 'Proposition of establishing a National Children's Museum and Folkart Workshop' (1978). BÁNSZKY speaks about human - especially childhood creativity stressing the importance of playing in the development of personality. These evidences (that are evidences for $u s$ and now) soon found supporters among civilians and professionals ${ }^{26}$. In his programme and function plan (June, 1979) the initiator of Tokaj experiments, the founder of the Museum of Hungarian Naive Arts aimed at turning children of 3-10 into creative persons with the help of the Kecskemét Playhouse. Thus in the late autumn

\footnotetext{
${ }^{26}$ KERÉNYI (1992: 77-80).
} 


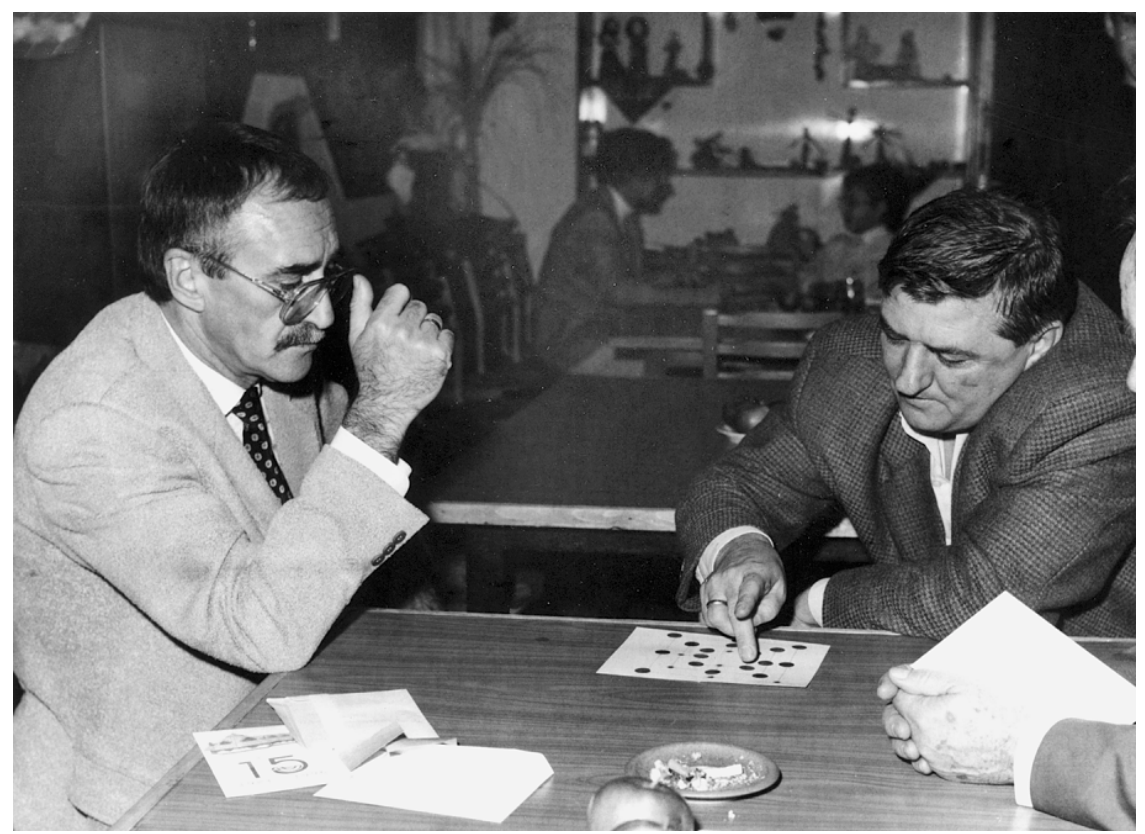

Fig. 5. Game festival on the 15th Anniversary of SZÓRAKATÉNUSZ. 5th December, 1996

of that year the foundation of the newest creative workshop of Kecskemét was started as the financial possibilities of the building seemed to be assured ${ }^{27}$. But the official name showing the real character of its double function was still missing. The name SZÓRAKATÉNUSZ was given in September 1981, when the advisory body of our institute suggested that we should change the name 'Playhouse' to the more expressive 'SZÓRAKATÉNUSZ Playworkshop and Museum'28.

Before the official opening the first Director of the SZÓRAKATÉNUSZ, Psychologist Dr Judit KOLOZSVÁRY (1981-1983) drew up the institute's programme for the first year containing names like for example Klára Kokas, Imre Montágh or Balázs Varga etc. as planned co-operators ${ }^{29}$. The town and village toys added to the basic material of the museum were lent to the museums of Szolnok, Nagykanizsa, Pécs, Szeged, Balassagyarmat, Szekszárd and also to the national museums. They

27 RAPI (1979: 5). The Ministry of Education, the county and town governments gave more than 5 million HUF to the building.

28 Pál BÁNSZKY's letter to Imre MAJOR, vice-president of the county government. Engineer Tibor SZENTIVÁNYI, owner of the most important logic-toy collection in Hungary, member of The National Play Adviser Body, founder of MELEDA (Adult Players Circle) and from 1987 to 1977 president of the Áron Kiss Hungarian Society for Play and Playthings- See: VÁCZI (1991: 17) and LUKÁCSY (1985: 332334).

${ }^{29}$ Dr. Judit KOLOZSVÁRY originally psychologist specialised on children acted as an adviser for one and a half year, although the building and the profile of the young institute was not really predestinated for this. See: KOLOZSVÁRY (1983: 14). 


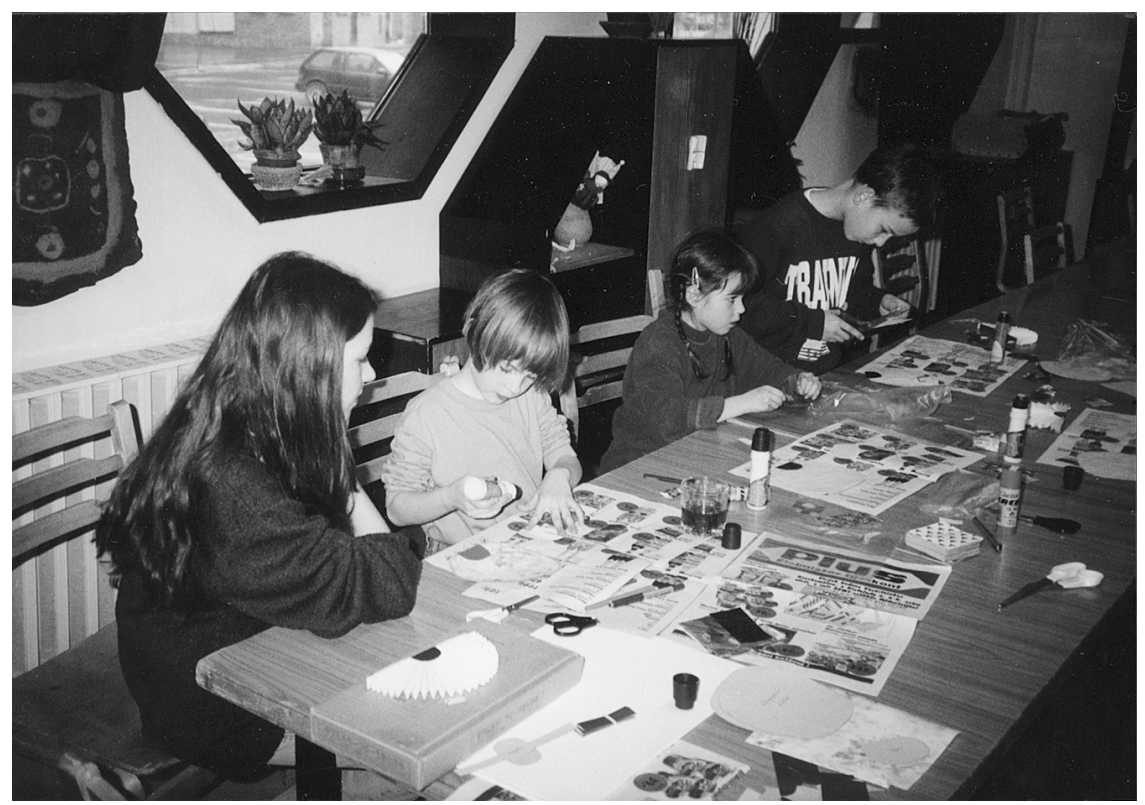

Fig. 6. Paper toys preparing in the workshop

were disposed by Dr Erzsébet GYÖRGYI and Edit HAIDER. The opening ceremony was held on 4th December with the assistance of Dr Mária Hanga, Deputy Minister. The popularity of the institute was proved by the thousands of visitors every month ${ }^{30}$ and the special attention of the press ${ }^{31}$.

In August, 1982 another conference (Tradition and Creativity) was held in Kecskemét organized by the Hungarian UNESCO Committee, the Education Research Institute and the Popular Education Institute - in appreciation of the work of the Kecskemét Toy Museum and Workshop. 'The Hungarian organizers provided a three-volume brochure mostly in English and in Hungarian... ${ }^{32}$. The meeting was divided into two parts. On the first two days there were demonstrative sessions... In the second half of the meeting everybody could tell his opinion about the connection of tradition and everyday creativity... Finally the conference passed recommendations to the chairman of the UNESCO.' writes József ZELNIK in his memorandum ${ }^{33}$.

The foreign and Hungarian experts were greeted by several papers ${ }^{34}$, and a popular playground with objects made of wood was set up for this occasion in front of the museum. It existed until 1989.35

\footnotetext{
30 RÉVI (1982: 36-39).

31 KOLOZSVÁRY-SZENTIVÁNYI (1983: 33-35).

32 ZELNIK (1982: 34).

33 ZELNIK ed. (1982b).

34 KALMÁR (1982: 87); KOLOZSVÁRY (1982: 25-27).

35 BÁNSZKY (1986: 3-4).
} 


\section{II}

a) The experiences of the previous years have convinced me that quite a great number of people heard about the institute, visited it, had an impression of its existence and work. So I am not going to give a fully detailed report on the 15 years of the museum. I can do so knowing that my colleague, Mária VÁCZI, gave short accounts of the events from 1982, and on our 10th anniversary she looked over the main efforts of SZÓRAKATÉNUSZ ${ }^{36}$. Mária NAGY, who is an industrial designer and a museum pedagogue, and István VIDÁK gave a survey of the educational work of the institute in an essay published somewhat later in Forrás ${ }^{37}$.

Following this logic, I would like to speak about publications and documentation of play events.

Besides the 'compulsory' exhibition guides and booklets I should mention the so-called 'methodology booklets' by Mária KARDOS and Mária NAGY ${ }^{38}$. Their experiences with nursery school children in creating toys and craft programmes were given over to thousands of nursery and junior school teachers.

Forrás, which is the periodical of Bács-Kiskun county, often published essays about play culture sometimes with a lot of illustrations. It was ten years ago that the periodical devoted a whole issue to playing ${ }^{39}$ with efficient treatises, papers on play and culture history, folklore, applied arts, literature and pedagogical essays. On the whole: 21 authors on 5 and a half printed sheets ${ }^{40}$.

In the same year we published 'A Book of Hungarian Ballgames' by Lajos PORZSOLT, a book that first appeared exactly 100 years ago. It also inspired us to prepare and publish the bibliography of important books and data ${ }^{41}$.

The writings of the above mentioned Forrás issue came in handy when on 21st23rd March, 1986 we organized the National Play Symposion in Kecskemét ${ }^{42}$. We planned to continue this type of programmes, but shorter meetings on a certain topic seemed to be more useful. The symposion remained memorable because of the exhibition from the material of the Second Room and Playground Toys Competition that was opened at the same time as the conference, and it gave topics to our conversations. This was the time when the idea of setting up a national play society occurred, its establishing declaration was prepared (from May, 1987 its name is Áron Kiss Hungarian Society for Play and Playthings).

36 VÁCZI (1986: 582-590) by the same author (1991) and a short summary by KRISTON VízI (1989: 350-358).

37 NAGY-VIDÁK (1992: 81-83).

38 KARDOS (1987); KARDOS-NAGY (1986). - See also: BEREZNAI (1992: 84-86). The first exhibition guide by KRISTON VÍZI (1984).

${ }^{39}$ Before that only one issue of "Müvészet" (Hungarian Art Quarterly) dealt with play and playthings in 1976.

40 Forrás (1985) No. 10. about Hungarian play-culture.

${ }^{41}$ KRISTON VÍZI (1985: 9-11).

42 As we have mentioned in the introduction of a book (published by the Áron Kiss Hungarian Society for Play and Playthings), the material of this volume is mostly taken from the lectures given here. KRISTON VízI (1996: 7-8). 


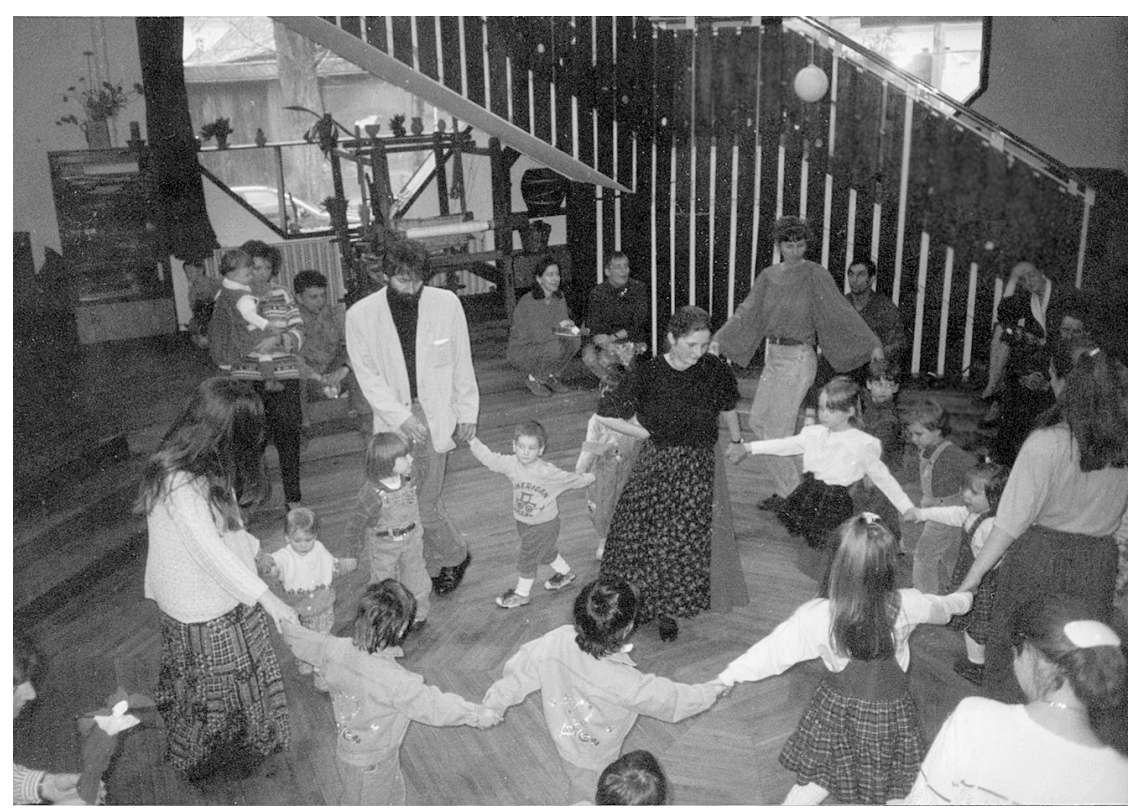

Fig. 7. Saturday afternoon family programme

The PORzSOLT book started a new series, the Play Culture History Studies, and we decided to publish important, old but short booklets that are difficult to get nowadays, so a play culture reprint series was also begun. Unfortunately we could publish only the first booklet of this series, Dezsô JózSEF's classical paper, The selfmade toys of children by the river Nyikó (Kolozsvár, 1943).

b) In the spring of 1990 a great collection of toys was given to the museum. With the help of Antal JÁNOSKA, the excellent playing-card collector and researcher, the heirs to Magician Rodolfo (Rezsó GÁCS, 1911-1987) presented our museum ${ }^{43}$ with his playcards.

This enabled us to start a new programme - causing more problems in the meantime - the playcards began their own life. Here they were as museum objects that needed closer studies. On the other hand, they were a popular plaything mostly among adults as objects of social life. This inspired us to study the adults' playthings as well, so this influenced the research and collecting work of our colleagues. The first Hungarian playcard history exhibition attracted a lot of visitors and was a great success. Two guides were prepared for $\mathrm{it}^{44}$. In March, 1991 an international playingcard mini-symposion was organized with English, German and Austrian guest lecturers. As a result of this a travelling exhibition was shown in different towns for 3

\footnotetext{
43 Later the best of his magician requisites and career documents.

44 JÁNOSKA (1990) and RAGG-KRISTON VÍZI (1991).
} 


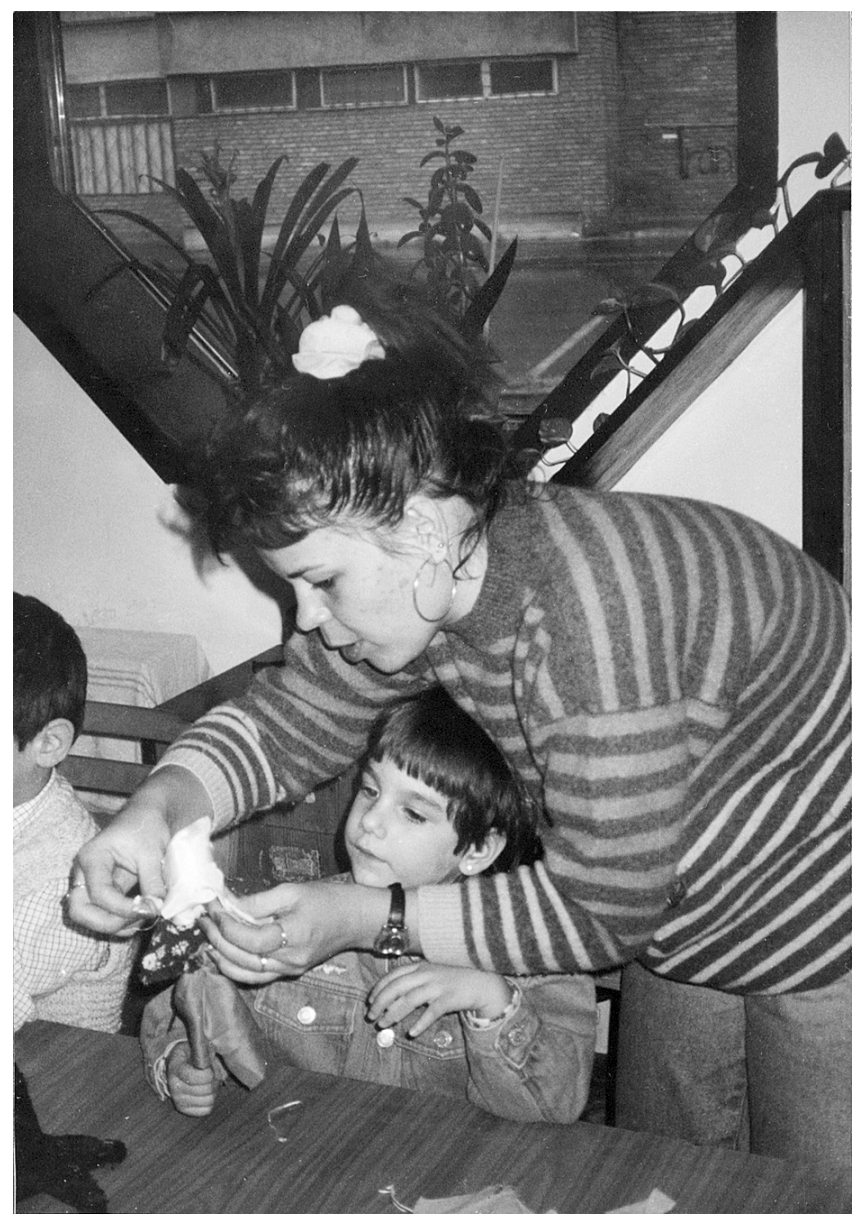

Fig. 8. Preparing of the rag doll

years supported by PIATNIK, Vienna, and a brochure was prepared in English introducing the Hungarian playcard manufactures. This symposion inspired the Austrian and Hungarian playing-card researchers and collectors to set up a society in 1992 under the name TALON ${ }^{45}$.

Our tenth anniversary brought forth doubts as well: how to go on? Alone or finding new people, new tasks with sometimes blind jumps into the unknown, or carefully withdrawing? Shall we be brave or rather conservative? On 6th December, 1991 an invitation was published that shows our dilemmas:

45 TALON meets yearly - one year in Hungary, the other year in Austria or Germany, too. Copresidents: Mag. Klaus Reisinger (Wien) and Horváth, Ferenc (Budapest). In the autumn of 1995 the Hungarian collectors formed the Hungarian Talon Foundation. 


\section{"INVITATION}

to lawyers, scientists, artists, researchers and practitioners of society and religion

to organize the independent SCIENCE ON PLAY

1. Let's make playing activity be proved as primary means of studying the world, getting information and knowledge, and be declared as an elementary right of children. ('If somebody is unexperienced in something, he remains a child in it' says Kodály.)

2. Scientific research should lead to clarifying concepts and meanings, becoming parts of everyday language. Clearing up misconcepts about play, the subordinate position of this basic human activity should be ceased.

3. Researches so far have shown that playing is a science of 'cosmic' measures, so it can't do without other sciences.

4. All knowledge fields should draw up which play activity contains parts of its field, or how playing can help us gaining certain knowledge. Results so far and bibliographies should be collected.

5. To reach this aim it seems to be important to found a PLAY STUDYING SOCIETY which - besides organizing tasks - should have:

- a data collecting department;

- a researching and publishing department in order to receive and arrange data.

6. On the basis of data collecting and research preparations should be started to publish:

- a dictionary of play terminology;

- a guide to play taxology

- a play encyclopaedia

in order to create the scientific and everyday play language.

7. The developing science should work its way into the system of sciences, should cover the blank stain waiting for it.

Toy Museum Kecskemét, 6th December, 1991, on the tenth anniversary of the museum

Dr József KRISTON VÍZI

László POLÁK”

\section{III}

1992 called forth this heap of tasks - with the prospects of new forms and ways. This is also the part of the recent past, a typical example of our miscarried enthusiasm: the establishing of the 'Homo Ludens' National Committee of Village Toys and 
Play $^{46}$, its functioning until the summer of 1994, finally giving up the EXPO '96 in Hungary. These years and events do characterise our situation well, the altruistic concentration of forces either of individuals or of communities on the one hand, and the contingency of treating the case of play and playthings on the society's (sometimes government's) side, on the other. The introduction and popularization of our folk activities was sometimes accompanied by jealousy and sometimes by rivalry in its positive sense, programmes and meetings followed each other, a lot of toy and play centered EXPO projects were prepared, but recently their number has lessened owing to mainly financial problems. I hope it will sound neither haughty nor baseless lamentation but SZÓRAKATÉNUSZ remained alone in realizing the plans of calling people to play in the future...

Finally, let's see what these are.

Expanding the Central-European 'neighbour visiting' began in 1993 with Czech and Slovakian partners and continued with southern people: to the East Zagorsk, to the North Kielce ${ }^{47}$, to the West Salzburg (where there is a museum and a famous play institute already), to the South - until weapons allow us to... Our position must be strengthened here, our tasks tie us here, the famous, thick-walled exhibition halls are examples for us but not 'rich relatives' to copy. The thoughts of István Györffy, which have been mentioned more and more frequently, have become timely: Japan, England, the USA, and Mexico or France do not want to see themselves here - they are interested in us, in our values.

And the workshop?

It has already taken off the old fashioned name 'playhouse', and has become well known in the world for its felt making. And it needs more and more place to work and to show.

So in these years that do not seem rich we wish to grow, although it may sound unrealistic. ${ }^{48}$ Even if we plan new computers to our new SZÓRAKATÉNUSZ, adjusting modern technics to our treasures, we need more room for our play!

\section{LITERATURE}

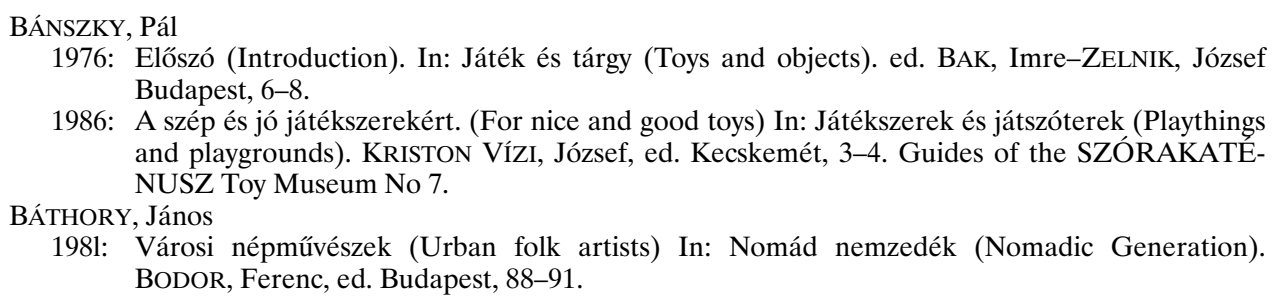

1976: Előszó (Introduction). In: Játék és tárgy (Toys and objects). ed. BAK, Imre-ZELNIK, József Budapest, 6-8.

1986: A szép és jó játékszerekért. (For nice and good toys) In: Játékszerek és játszóterek (Playthings and playgrounds). KRISTON VíZI, József, ed. Kecskemét, 3-4. Guides of the SZÓRAKATENUSZ Toy Museum No 7.

1981: Városi népmúvészek (Urban folk artists) In: Nomád nemzedék (Nomadic Generation). BODOR, Ferenc, ed. Budapest, 88-91.

\footnotetext{
46 HÁMORI-SZILVÁSSY (1992).

47 The Polish Toy Museum (founded in 1979) can be found here.

48 Information sheet by VÁCZI, Mária (Secretary).
} 
BEREZNAI, Zsuzsanna

1992: A SZÓRAKATÉNUSZ kiadványai. (SZÓRAKATÉNUSZ publications) In: Forrás, XXIV. 84-86., Kecskemét.

FARAGÓ, József-FÁBIÁN, Imre

1982: Bihari gyermekmondókák (Nursery rhymes from Bihar county, Romania). Bukarest.

GAZDA, Klára

1980: Gyermekvilág Esztelneken (Children's life in village Esztelnek) Bukarest.

1981: Az esztelneki gyermekjátékok romániai párhuzamai. (Similarity of children's play in Esztelnek and other Romanian villages) In: ALUTA 247-268. Sepsiszentgyörgy.

GÁGYOR, József

1982: Megy a gyúrú vándorútra. Budapest-Bratislava I-II.

GUNDA, Béla

1981: Múvelődéstörténeti jegyzetek a magyar gyermekjátékokhoz (Culture-historical notes on Hungarian children's plays). Ethnographia XCII. 65-68.

GYÖRGYI, Erzsébet

1982: Magyar paraszti gyermeknevelés (Educating children in villages) In: GYÖRGYI, Erzsébet ed. Hagyomány és kreativitás (Tradition and creativity) I, Budapest-Kecskemét.

1983: A gyermek a hagyományos paraszti kulturában (Children in traditional folk culture). In: Gyermekjátékok (Play and games of children). HÉRA, Istvánné, ed. Budapest 13-25.

1990: Kiss Áron halálának évfordulójára (On the anniversary of the death of Áron Kiss). In: Vesszőparipáink I. KRISTON VíZI, József, ed. Kecskemét-Budapest, 14-16.

HÁMORI, Tamás-SZILVÁsSY, István

1992: Homo Ludens. Project of traditional games in Hungary. Budapest.

HiNTALAN, László-LÁzÁR, Katalin

1980: Gyermekjátékok. (Folk games, plays and toys of children in the village Hévizgyörk) Pest megyei Múzeumi Füzetek XII, Szentendre.

Hollós Róbertné

1982a: Játszóházak (Playing houses). In: Múvészet-Oktatás-Játék (Arts-Education-Games). Hosszú, Klára, ed. Budapest-Kecskemét, 32-33.

1982b: Játék-kultura a Magyar Nemzeti Galéria GYIK-múhelyében. (Play culture in the Workshop of the Hungarian National Gallery) Experiments. In: Oktatás-Múvészet-Folklór-Játék. Hosszú, Klára, ed. Budapest, 105-107.

JÁNOSKA, Antal

1990: Az ördög bibliája (The "Bible of Devil"). Kecskemét.

JÓZSEF, Dezsó

1992: A Nyikó-menti gyermek magakészítette játékszerei. Kolozsvár, 1943. (Hasonmás: Kecskemét).

KALMÁR, Ágnes

1982: Népi játékok Kecskeméten (Folk toys in Kecskemét) . Forrás, XIV. No. 8. 87., Kecskemét.

KARDOS, Mária

1987: Mintázások, agyagos munkák (Pottery, clayworks). Kecskemét.

KARDOS, Mária-NAGY, Mari

1986: Játékkészítés és kézmúvesség óvodásokkal (Toy creating and handicraft work with nursery school children). Kecskemét.

KARLÓCAI, Marianne

1981: Ugróiskolákról - játszóházaknak (Hopscotch for playhouses). Budapest.

KATONA, Imre

1979: Gyermekfolklór (Folklore of children). In: A magyar folklór (Hungarian folklore). ORTUTAY, Gyula, ed. Budapest, 375-391.

1981: Szempontok a mai gyermekjátékok gyújtéséhez. (Aspects of collecting toys of these days) In: Előzmények és tervek... 52. Budapest.

K. CSILlÉRY, Klára

1981: A parasztgyermek helye a lakásban (The place of the children in a traditional village house). Ethnographia, XCII. 61-65.

KERÉNYI, József

1992: A Játékmúhely és vidéke. 10 éves a kecskeméti SZÓRAKATÉNUSZ (The playworkshop and its circumstances. The Kecskemét SZÓRAKATÉNUSZ Museum is ten years old) Forrás, XXVI. No. 3. Kecskemét, 77-80. 
KOLOZSVÁRY, Judit

1982: A SZÓRAKATÉNUSZ Játékmúhely és Múzeum ("SZÓRAKATÉNUSZ” Toy Museum and Workshop). In: Oktatás-Múvészet-Folklór-Játék. ed. Hosszú, Klára, Budapest-Kecskemét, 25-27.

1983: Rendhagyó osztályfőnöki órák (Irregular formmaster’s lessons) Manuscript, Jáma (Archives of the SZÓRAKATÉNUSZ Toy Museum), 9-84. Kecskemét 1-14.

KOLOZSVÁRY, Judit-SZENTIVÁNYI, Tibor

1983: Játékmúzeum Magyarországon (Toy Museum in Hungary). In: Rubik s... És játék! No. 3. 3335 .

KOMLÓSI, Előd

1979: Legényszervezetek és az ifjúság téli mulatságai. (Lads’ organizations and possibilities of amusement for young people in the winter) Ethnographia, XC, 92-105.

KovÁCS, Emese

1983: Beszámoló... “A mai folklór” kutatások keretében folyó gyermekfolklór-kutatásokról, 19811982. (An account on the researches of children's folklore). In: Előzmények és tervek... No. 84. Budapest.

KRISTON VÍZI, József

1978: A gyermekek és az ifjúság életéhez kapcsolódó játékok... (Games in children’s and young people's life). A miskolci Herman Ottó Múzeum kérdőivei. Miskolc.

1981: Játék és szórakozás Pusztafaluban (Playing and amusement in Pusztafalu). In: Néprajzi tanulmányok a Zempléni-hegyvidékről.. VIGA, Gyula, ed. Miskolc, 335-347.

1984: Nagyszüleink játékai városon és falun (Games and toys of our grandparents in towns and villages). A SZÓRAKATÉNUSZ kiállitásvezetői I. Kecskemét.

1985: Önálló múvek és jelentősebb cikkek a labdajátékok témakörébôl. In: PorzSOLT, Lajos: A magyar labdajátékok könyve. 1885, 9-11. (Hasonmás: Kecskemét).

1987: Játékszerek, játszóterek (Playthings and playgrounds). Kecskemét.

1991: A museum of a new type in Hungary. The SZÓRAKATÉNUSZ Toy Museum of Kecskemét. Acta Ethnographica, 350-358.

1996a: Európai Játékház, avagy 15 éves a SZÓRAKATÉNUSZ (European playhouse. The SZÓRAKATÉNUSZ Museum is 15 years old). Forrás, XXVIII. No. 10. 55-58.

1996b: Játék-Rend-Szerek, (Game Systems). Vesszőparipáink, III, Kecskemét-Budapest.

LACZKOVITS, S. Emóke

1980: Adalékok a falusi gyermekek életéhez Veszprém megyében, 1868-1945. (Some facts about the life of village children in Veszprém county). Veszprém megyei Múzeumok Közleményei. Veszprém, 237-272.

LUKÁCSY András

1985: Elmés játékok, játékos elmék (Witty plays, playful wits). Budapest.

MAKOVECZ, Imre

1981: A tokaji ház (A house in Tokaj). In: Nomád nemzedék (Nomadic generation). BodoR, Ferenc, ed. Budapest, 91-101.

NAGY, Mari-VIDÁK, István

1980: Játékok vízparti növényekból (Toys made of water plants). Budapest.

1992: Mûvészetre nevelés a Játékmúhelyben. (Teaching methods to enjoy arts). Forrás, XXIV. Kecskemét, 81-83.

PIRK, Ambrus

1979: Játékról komolyan (Seriously about playing - mostly playthings and playgrounds) Budapest.

POLÁK, László

1981: Gyermekélet (Children's life). Kérdőív. Budapest.

RAGG, Ernst Rudolf-KRISTON VíZI, József

1991: Játékkártyák Magyarországon (Plaing-cards in Hungary). Piatnik, Wien.

RAPI, Miklós

1979: Milyen lesz a kecskeméti gyermekjátékház és múzeum? (What will the museum and playing

RÉVI, Judit house be like in Kecskemét?) Petófi Népe, November 29, 5. Kecskemét.

1982: Játékmúhely és múzeum (Toy-workshop and Museum) Népmúvelés, No. 4. 36-39.

VÁCZI, Mária

1986: A SZÓRAKATÉNUSZ naplójából, 1981-1984. (From the diary of SZÓRAKATÉNUSZ) Cumania 10, Kecskemét, 582-590. 
VÁCZI, Mária

1991: A SZÓRAKATÉNUSZ naplójából (From the diary of SZÓRAKATÉNUSZ), 1981-1991. Kecskemét.

1993: Informations about the Foundation on SZÓRAKATÉNUSZ European Centre of Toys, Kecskemét.

VOIGT, Vilmos

1979: A folklorizmus és a gyermekfolklór kérdései a mai folklórkutatásban (The questions of folklorism and children's folklore in today's researches) Előzmények és tervek a Folklór Tanszékról, No. 6. Budapest.

ZELENÁK, Katalin

1981: Játszóházak Bács-Kiskun megyében (Play-houses in Bács-Kiskun county). Népmúvelés, No. 12, $28-30$

ZELNIK, József

1979: Játék - Kultura (Playing-culture). Exhibition guide. Budapest

1981: A folyamatosság kísértése. (The temptation of continuity) In: Nomád nemzedék (Nomadic generation). BODOR, Ferenc, ed. Budapest, 6-9.

1982a: Hagyomány és kreativitás (Tradition and Creativity). I-III. Kecskemét-Budapest.

1982b: Néphagyomány és kreativitás ma (Folk tradition and creativity today). Népmúvelés, No. 10. 34. 